\title{
The Impact of Cooperative Learning on Developing Speaking Ability and Motivation Toward Learning English
}

\author{
Ehsan Namaziandost \\ Islamic Azad University \\ Correspondence concerning this article should be addressed to Ehsan Namaziandost, Department of \\ English, Faculty of Humanities, Shahrekord Branch, Islamic Azad University, Shahrekord, Iran. \\ E-mail: e.namazi75@yahoo.com \\ Vida Shatalebi \\ Islamic Azad University \\ Correspondence concerning this article should be addressed to Vida Shatalebi, Department of English, \\ Najafabad Branch, Islamic Azad University, Najafabad, Iran. E-mail: vi_shatalebi@yahoo.com \\ Mehdi Nasri \\ Islamic Azad University \\ Correspondence concerning this article should be addressed to Mehdi Nasri, Department of English, \\ Faculty of Humanities, Shahrekord Branch, Islamic Azad University, Shahrekord, Iran. \\ E-mail: me_nasri@yahoo.com
}

This study aimed to investigate the effectiveness of cooperative learning in English language classrooms to enhance Iranian students' speaking skills and motivations. A pre-test-post-test control group design was employed to compare the impact of the cooperative learning approach with that of traditional whole-class instruction on speaking skills and six aspects of learning motivation: intrinsic motivation, integrated regulation, identified regulation, introjected regulation, external regulation, and amotivation. The data of the current study were gathered at multiple points of time before and after the end of the experiment to determine the effectiveness of cooperative learning on the sample's speaking skills and motivations. In practical terms, the sample's speaking skills were first examined through an English oral test prior to and after some cooperative learning instructional activities were provided. Next, a seven-point Likert scale-questionnaire was administered to the sample before and at the end of the course to check students' motivation towards the use of cooperative learning in English classes. The data were analyzed using basic and inferential statistical methods including mean scores, standard deviations, independent and paired sample t-tests, one-way ANCOVA, and effect size. The findings showed remarkable development in the students' speaking skills after the introduction of cooperative learning techniques. Moreover, the findings suggested significant differences in favor of cooperative learning for improving intrinsic motivation, but no differences were found on other aspects of motivation. In light of the findings, the researchers recommend that teachers could benefit from applying CL in English classes, which may in turn develop students' speaking skills and motivation.

Keywords: Cooperative learning; EFL; English speaking skills; intrinsic motivation; integrated regulation; identified regulation; introjected regulation; external regulation; amotivation 


\section{Introduction}

Foreign language teaching in Iran seems to be quite outdated. Traditional methods like Grammar Translation Method (GTM) continue to be used. Old methods used in teaching English in Iranian schools failed to motivate the students and instigate their involvement in class activities; this is why these methods are structurally based. The grammar-oriented methods that are widely used in the Iranian educational system are not producing the desired results for real communication (Tahmasbi, Hashemifardnia, \& Namaziandost, 2019). Accordingly, textbooks are structurally oriented and often not relevant to students' needs; too much emphasis is placed on the learning of grammar and vocabulary. Although successful and fluent communication is the final goal of EFL learners, little effort is made to actually help them learn to speak English as it is spoken by native speakers. Therefore, Iranian learners have lots of problems interacting with their interlocutors in the target language. Many Iranian EFL learners are grammatically proficient and they know an abundance of English words but they are unable to communicate fluently. In addition, after studying English for some years, numerous of EFL learners are not satisfied with their speaking proficiency level and become demotivated gradually (Keshmirshekan, Namaziandost, \& Pournorouz, 2019).

English speaking skill is one of the four macro abilities needed to communicate effectively in any language, especially when students do not use their mother tongue. This ability is the concrete use of language and a means by which people interact with others (Namaziandost \& Ahmadi, 2019). As indicated by Harmer (2008), language learners utilize every language they understand when they talk. Furthermore, speaking is a significant language teaching ability that allows language learners to interact not only in terms of their perspectives but also in terms of their answers (Richard, 2008; Ur, 2012). This ability is described, according to Soleimani and Khosravi (2018), as a policy method incorporating students in the use of language for the intent of attaining a specific speaking task.

Participating in English conversation courses and concepts of motive in studying a foreign language have been regarded as a significant problem in language teaching for more than four centuries. English oral communication in the academic realm is thought to be essential (Omer \& Attamimi, 2014; Pattanapichet \& Chinaokul, 2011). Traditional models of foreign language teaching place emphasis on the description of vocabulary, grammar, and other things in writing by educators. Learners could not understand new languages rapidly. Kayi (2006) believes that "language teaching has been evaluated for many years and English language teachers continue to teach language as a reiteration of drills or retention of lectures" (p.1). Traditional techniques of learning used in courses make learners feel tired (Amedu \& Gudi, 2017; Nasri, Namaziandost, \& Akbari, 2019).

There are four major problems in English teaching classes in Iran and they include: 1. Teacher-centered classes 2 . Competition rather than cooperation 3 . Unfamiliarity of teachers with cooperative learning mechanisms 4 . Students' minimum knowledge of English proficiency. (Bagheri, Dabaghmanesh \& Zamanian, 2013).

So, after a few years of learning English, learners are still unable to talk about the climate even though they understand a bunch of English language phrases and rules. A suitable technique that can be regarded as a substitution for traditional speaking training is co-operative teaching. It is used as a replacement for learner's instruction to improve speaking and social communication. (Namaziandost \& Ahmadi, 2019; Ning, 2011).

In recent years, the change from a teacher-centered teaching model to a learner-centered model has been one of the biggest modifications in foreign language pedagogy. This change marks a fresh period in which Englishspeaking training must offer learners an opportunity to speak the language. Co-operative teaching acts as an alternative method for teaching by promoting speech and social interaction (Hernández \& Boero, 2018; Russell, 2018). A study of the associated literature disclosed that most of the past research studied the implementation of cooperative learning (CL) in particular and its overall impact on the capacity of the student, rather than exploring the impacts of particular structures on the capacity of the student to generate and comprehend significant texts (Namaziandost, Rahimi Esfahani, Nasri, \& Mirshekaran, 2018; Ning, 2011; Ning \& Hornby, 2010). In Iran, however, the impact of cooperative learning on teaching English speaking skill has not been investigated. In this study, the researchers compared cooperative learning instruction to traditional instruction to discover the impact of cooperative learning instructions on students' English-speaking ability and motivation. 
Traditionally, teacher-centered English courses were more common in Iranian classrooms (Nasri \& Biria, 2017) and this technique likely impeded the speaking abilities and behavior of learners. There was inadequate communication and interaction between learners and educators in the school to help English-speaking learners improve, and Iran's labor demands were also rarely met.

Speaking practice in Iranian universities has been revealed to continue to enhance the advancement of learners' speaking in general (Nasri \& Biria, 2017; Al-Sohbani, 2013). Speaking in most Iranian classrooms is mainly done by the teachers, who are deemed to be the authority of the school, and learners have no opportunity to exercise their language abilities and find it difficult to express their abilities and thoughts in English (Al-Sohbani, 2013).

The use of cooperative learning in teaching speaking has been the subject of extensive research (Al-Tamimi, \& Attamimi, 2014; Bagheri, Dabaghmanesh, Zamanian, 2013; Kandasamy, \& Habil, 2018; Nasri \& Biria, 2017). A huge number of studies indicated that the utilization of cooperative learning techniques can result in positive attitudes towards cooperative learning and increased speaking skills (Alharby, 2015; Nasri \& Biria, 2017; Suhendan \& Bengu, 2014). Cooperative learning methods, which vary from traditional learning methods, have a few advantages resulting from social cooperation between students (Leong \& Ahmadi, 2017; Namaziandost, Nasri, \& Rahimi Esfahani, 2019). Classroom social interactions, according to Mackey (2007), are effective for overall language progress. It has been seen that learners who interact and speak more usually achieve better progress in oral skills than those who always keep silent (Namaziandost, Hashemifardnia, \& Shafiee, 2019).

English speaking skill is one of the most significant abilities to be created and improved in language students, especially in a scholarly setting (Morozova, 2013). Therefore, there is a need to improve the present degree of speaking skill among college learners in Iran. This calls for a quick change to be made. As noted, the impacts of cooperative learning on learners' speaking skills and frames of mind have been frequently shown and affirmed by studies led in L1 and L2 learning situations (e.g. Namaziandost, Nasri, \& Rahimi Esfahani, 2019; Ning, 2011; Talebi \& Sobhani, 2012; Pattanpichet, 2011; Sühendan \& Bengü, 2014). However, studies in this area with EFL students in Iran are rare. Therefore, further investigation to examine whether the positive effect of cooperative learning also holds true for enhancing Iranian students' speaking skills and attitudes still calls for empirical validation. Thus, it is the view of the researchers that Iranian university students can improve their academic performance if they are taught or instructed to become effectual and competent speakers.

Taking all the above into account, there seems to be an immediate necessity to produce a cooperative learning environment in Iranian EFL classrooms to develop students' speaking skills and attitudes, where teachers work as facilitators in the learning process and motivate creativity and cooperation among students. With these research incentives in mind, the researchers formulated the following research objectives and questions.

\section{Research Questions}

This study addresses the following research questions:

RQ1. Does cooperative learning have any significant effect on developing students' speaking skills?

RQ2. What is the effectiveness of the CL approach for improving students' learning motivation, compared with traditional instruction, in English teaching at a university in Iran?

\section{Significance of the Study}

The importance of the study springs out of the fact that CL plays a major role in language learning contexts. Current research seems to validate this view that cooperative learning increases social interactions among students and consequently leads to improving communication skills among them. University teachers will benefit from this study through using the up-to-date teaching methods used in the study, i.e. cooperative learning. English language classrooms should no longer be dominated by the teacher but should be more studentoriented, with the teacher adopting the role of facilitator. By doing so, it adds variety to teaching and learning contexts and makes it fun for the students to improve their speaking skills. Furthermore, there are no studies, to our knowledge, investigating the effects of cooperative learning on improving university students' speaking skills and attitudes in Iran. There is insufficient research, particularly in Iran, to draw any firm conclusions on the centrality of cooperative learning in the teaching and learning process of English. 


\section{Theoretical Background}

The basic theoretical premises of cooperative learning and speaking performance are presented in this section. In addition, some previous studies that were carried out to examine the effects of cooperative learning on developing students' speaking skills and motivation are reviewed.

\section{Cooperative Learning}

Cooperative learning is defined as a set of instructional methods through which students are encouraged to work on academic tasks (Namaziandost, Nasri, \& Rahimi Esfahani, 2019). It also refers to a teaching technique where students work in groups on a certain activity in order to maximize one another's learning and to achieve certain goals (Nasri \& Biria, 2017). In CL, students work in small groups to help one another learn academic content (Amedu \& Gudi, 2017). The teaching and learning process using CL techniques is a learner-centered paradigm that has gained popularity as an alternative to the lecture-based paradigm. Much of the current research revolves around the notion that CL has positive effects on various outcomes (Johnson \& Johnson, 2003). Most studies on the effects of CL have consistently indicated that this method improves students' English oral skills (Pattanpichet, 2011), English reading comprehension (Bolukbas, Keskin, \& Polat, 2011), and English writing (Nasri \& Biria, 2017).

The role of teachers using the CL method shifts from transmitters of knowledge to mediators of learning (Nasri \& Biria, 2017). This role involves facilitating, modeling, and coaching. Teachers adopting this role should maintain a safe, non-threatening, and learner-centered environment. This environment of teaching will help students contribute positively in the cooperative activities assigned to their group (Ning, 2011). For the activities to be genuinely cooperative, each type of activity requires the presence of five basic components of the CL (Namaziandost, Abdi Saray, \& Rahimi Esfahani, 2018). Given the centrality of this concept to the current study, the CL basic components are given below.

\section{Basic Components of CL}

There are five key components that differentiate CL from simply putting students into groups to learn (Johnson, Johnson, \& Smith 2006). The first one is positive interdependence. It refers to the idea that students are required to work together in order to achieve common learning objectives. In this case, students must believe that they are linked and that they either sink or swim in such a way that one cannot succeed if the others do not. Students need each other for support, explanations, and guidance. Without the assistance of the members, the group will not be able to accomplish the ideal goal. The second one is singular responsibility. It infers that each team member is responsible for his/her fair share to the group's prosperity. It is vital that the group knows who needs more help, support, and encouragement while working on a task. It is additionally fundamental that group members know they cannot "hitchhike" on the work of others (Al-Tamimi \& Attamimi, 2014). It needs each student in the group to display a sense of personal responsibility to learn and help the rest of the group to learn as well. The third component is promotive interaction. It alludes to the connection of students in order to help them accomplish the task and the group's shared goals. Students need to interact verbally with one another on learning tasks (Tesfamichael, 2017). They are also expected to elucidate things from each other, train others, and provide each other with assistance, support, and encouragement. The fourth component is interpersonal and social skills. It refers to skills such as giving helpful feedback, reaching consensus, communication accurately and unambiguously, and involving every member in the learning process. However, not all students know these skills. They must be taught and practiced these skills before the groups tackle a learning task. Therefore, teachers should carefully and explicitly teach their students the required skills. The teacher is not a person who measures the capacities of the students in terms of the final product, but somebody who acts as a friend, coordinator, director, guide, counselor, and facilitator (Tesfamichael, 2017). Finally, group processing is an important aspect of CL. It requires group individuals to survey their capacities and commitment to the achievement of all tasks. It centers around positive practices and activities rather than on negative ones and includes learners contemplating how they learn. The educator may also elect to spend time explicitly concentrating on improving a skill, for example, speaking. The educator would then be able to screen the various groups during the learning exercises and give feedback on what has been observed. 


\section{Speaking Skill}

Speaking is the verbal use of language and a medium through which human beings communicate with each other (Lazaraton, 2014; Namaziandost, Abedi, \& Nasri, 2019). It is the most important skill that people need to communicate in everyday situations. Generally, speaking is the ability to express something in a spoken language. It is putting ideas into words to make other people grasp the message that is being conveyed. In this study, the term "speaking" is one of the four skills related to language teaching and learning.

At present, English is widely used as an instrumental language for various purposes and enjoys a higher status than in the past (Namaziandost, Abedi, \& Nasri, 2019). According to Kandasamy and Habil (2018), English in the world is now associated with advancement in technology, trade, tourism, the internet, science, commerce, politics, and so forth, which has made English the most important language in different aspects of life. As a result, the ability to speak is required in many of the above fields, if not in all of them. However, most Iranian EFL students have difficulties in speaking English. They have troubles with pronunciation, vocabulary, grammar, fluency, and comprehension.

Considering the aforementioned problem,EFL teachers should train students to develop their oral communication. According to Brown (2007), oral communication can be maintained by having three components. The first one is fluency, which is the ability to speak spontaneously and eloquently with no unnatural pausing and with the absence of disturbing hesitation markers. It also refers to some aspects like responding coherently within the turns of the conversation, using linking words and phrases, keeping in mind comprehensible pronunciation and adequate intonation without too much hesitation (Mishan, \& Timmis, 2015; Namaziandost, Abedi, \& Nasri, 2019). The second component is accuracy. It refers to the mastery of phonology elements, grammar, and discourse. It also refers to the linguistic competence that deals with the correction of utterances to obtain efficient communication. According to Thornbury (2005), speaking English accurately means doing so without errors, or with only a few errors in grammar as well as in vocabulary and pronunciation. The third component is pronunciation. It is "the production and perception of the significant sounds of a particular language in order to achieve meaning in the context of language use. This comprises the production and perception of segmental sounds of stressed and unstressed syllables and of the speech melody or intonation" (Metruk, 2018; Shantha, \& Mekala, 2017). Without good pronunciation, listeners cannot understand what another person says and this will make the communication process more difficult. Therefore, pronunciation plays a central role in both academic and social fields in the way that students can be able to participate and integrate successfully in their community. In conclusion, fluency, accuracy, and pronunciation are three important and complementary components in the development of students' speaking skill.

Given the main components of speaking skill, EFL instructors need to introduce speaking activities. The types of activities that can be used are performance, guided, and creative activities. The choice of these activities depends upon what we want the learners to do. The first activity type is performance activities. They provide students with opportunities to communicate in the target language. Teachers and students at this point should concentrate on the meaning and intelligibility of the utterance, not the grammatical correctness. With practice, grammar errors should disappear. The second is guided activities. They include repetition practice or set sentences prompted by picture or word cues, and aim to improve the accurate use of words, structures, and pronunciation. In guided activities, the focus is usually on accuracy and the teacher makes it clear in the feedback that accuracy is important. Some examples of activities for controlled practices are: Find Someone Who, questionnaires, information gaps, etc. Guided activities include model dialogues that students can change to talk about themselves and to communicate their own needs and ideas, and tasks that the students carry out using language taught beforehand. Finally, creative activities are usually designed to give either creative practice opportunities for predicted language items, or general fluency practice, where the specific language focus is less relevant. Some activities for freer practice are: interaction or information gap, role-playing, simulations, free discussion, games, a jigsaw activity, and problem-solving. These activities are combined with cooperative techniques to motivate students and improve their speaking skill (Hedge, 2008; Kandasamy \& Habil, 2018). These types of activities are important in teaching language for communication and help create interactions in the language classroom (Kumaran, 2017; Namaziandost \& Rahimi Esfahani, 2018).

In a nutshell, there is a need to investigate the use of CL instruction in teaching speaking in Iranian classrooms. This can be done through carrying out experimental studies to investigate the effect of CL in enhancing students' 
speaking skill and motivation. It is very important for students to attain good competence in speaking skills as being a skilled speaker is becoming crucial for expressing one's thoughts inside and outside schools.

\section{Experimental Studies}

Many researchers have conducted studies to find out how better to use CL for developing students' speaking skills and attitudes at the tertiary level. Pattanpichet (2011) conducted an experimental study to investigate the effects of using CL to promote students' speaking achievement. Thirty-five undergraduate students participated in the study. The students were enrolled in a required English course at Bangkok University to examine their speaking achievement on an oral English test before and after they had participated in instructional tasks based on the cooperative learning approach. To explore the students' views on the use of the CL, they were asked to complete a student diary after finishing each task, fill in a four-scale rating questionnaire, and join a semi-structured interview at the end of the course. The data were analyzed by frequency, mean, standard deviation, t-test, effect size, and content analysis. The findings reveal the improvement of the students' speaking performance and positive feedback from the students on the use of collaborative learning activities. The study provides suggestions and recommendation for further investigations.

Talebi and Sobhani (2012) conducted a study on the impact of CL on English language learners' speaking proficiency. Experimental design was used with 40 male and female students as a sample enrolled in a speaking course at an IELTS Center in Mashhad, Iran. They were randomly assigned to control and experimental groups. The two groups were homogeneous in terms of their oral proficiency before carrying out this study. An oral interview was conducted to collect the data for the study. The control group received instructions in speaking; three sessions per week for one month, while the experimental group was taught speaking skills through CL. The results of the study showed that the performance of the experimental group for the oral interview held at the end of the course outperformed the control group. The mean score of the experimental group was significantly higher than the control group.

An experimental study carried out by Ning (2011) to find out the effect of CL on enhancing tertiary students' fluency and communication. It aimed to offer students more opportunities for language production and thus enhance their fluency and effectiveness in communication. The test results showed students' English competence in skills and vocabulary in CL classes was superior to whole-class instruction, particularly in speaking, listening, and reading.

Ning and Hornby (2010) conducted a study to investigate the effects of CL on Chinese EFL learners' competencies in listening, speaking, reading, writing, and vocabulary. Participants were 100 first-year English learners from a university in the north of China. A pre-test-post-test quasi-experimental design was employed to study the effects of the CL approach on students' language competencies compared to traditional instruction. The findings revealed clear differences in favour of the CL approach in the teaching of listening, speaking, and reading but no differences were found between the two approaches in the areas of writing and vocabulary.

Sühendan and Bengü (2014) investigated ELT students' attitudes towards CL. A questionnaire was given to 166 $(\mathrm{F}=100, \mathrm{M}=66)$ university students whose ages were between 18-20 and were all studying in different faculties. A questionnaire on the students' attitudes regarding CL was administered. The collected data were analyzed using descriptive analyses. It was shown that $66.9 \%$ of the students were on the side of CL in ELT classes whereas $33.1 \%$ of them believed that they would have better results if they worked alone and thought working alone was more enjoyable. A focus group was organized and the students mentioned both positive and negative sides of cooperative work. Furthermore, the findings reported that there were differences in gender and attitudes towards CL that benefitted females.

Yang (2005) compared the effectiveness of CL and traditional teaching methods on Taiwanese college students' English oral performance and motivation towards learning. Sixty Taiwanese college students from two intact classes were involved in the study. A quasi-experimental with non-equivalent control group pre-test-post-test design was used. The total experimental period was eight weeks of instruction. The subjects were administered a pre-test and post-test, using the intermediate-level speaking component of the GEPT (General English Proficiency Test) as well as the MIQ (Motivational Intensity Questionnaire) as a pre-test and post-test in the study. One-way ANCOVA was used to analyze the speaking component (intermediate level) of the GEPT scores 
and MIQ results. Data collection and analyses explored the effects of CL on the Taiwanese college students in terms of English oral performance and motivation to learn in favor of cooperative learning.

However, the search of the literature did not locate any study evaluating the impact of CL versus traditional teaching on university EFL learners' speaking ability and motivation for learning in Iran.

\section{Methodology}

\section{Research design}

Since randomization was not feasible, the current study employed quasi-experimental with a non-equivalent control group pre-test-post-test design. Two intact classes were selected through non-random assignment; one as a control group $(n=45)$, and the other one the experimental group $(n=45)$. The independent variable of this study is the CL method proposed for this study versus the traditional method used for teaching speaking. The dependent variables are the students' speaking skill and attitudes. The dependent variables were measured by comparing the students' speaking skills and attitudes in the pre-test with the students' speaking skill and attitudes in the post-test. The experimental group received instruction in speaking skills based on CL and the students of the control group were not exposed to this treatment as they were only exposed to the regular way of teaching followed in the college. Both groups were similar in sharing the same learning materials, schedule, and tests.

\section{Participants}

Ninety male EFL learners studying how to teach English as a foreign language (TEFL) at Islamic Azad University participated in this study. The subjects were of similar age, ranging from 20 to 22 years at the time of conducting the study. They were all homogeneous with regard to age, sex, ethnicity, mother tongue, exposure to English, and educational and cultural background. They were divided into two groups, 45 in the control group and 45 in the experimental group. In the experimental group, participants were divided into eight small groups and they were asked to undertake the speaking skill topics cooperatively using the speaking package. The CL techniques used with the intervention group were adapted from the Student Team Achievement-Division (STAD) (Slavin, 2014) and Numbered-Heads-Together (NHT) (Kagan \& Kagan 2009). Foursomes were used as home teams, with special consideration given to the heterogeneity of English proficiency within a team and homogeneity between teams. Each home team, for which membership remained constant for the whole semester, chose its own name and each member in a team was assigned a code name, which is essential for implementing NHT. The general organization of sessions took the form of the adapted STAD including three components - class presentation, structured teamwork, and team assessment. Class presentation by the teacher was via whole-class instruction related to reading texts, writing skills, vocabulary, or grammar, or a replay of audiovisual materials if it was in the listening and speaking class. The whole-class instruction was brief compared with that in the traditional teaching group, because many learning materials were set aside to be completed by teamwork. For a team assignment, teammates needed to agree beforehand where and when to meet, how to divide the team task according to individual interests and competence, and what additional learning resources to access.

The structure of NHT was modified to organize the teamwork and assessment processes as follows. First, teammates worked on tasks within a given time limit. Each task was based on textbook learning materials, and might be a five-minute class activity (e.g. brainstorming vegetable names) or a team assignment to be completed within a couple of weeks (e.g. preparing a 10-minute speech on "brain drain in developing countries: reasons and results" based on their knowledge, information from textbooks, and after-class cooperative research). A small amount of Persian was allowed for team discussion but not for presenting work. The teacher was available to provide scaffolding when necessary. Second, one team was randomly selected as a presenting team, and then a particular code name was randomly selected from the team. Third, the student with the selected code name from the team presented his/her home team's work in front of the whole class. Fourth, the student's performance was assessed against the pre-set criteria by peers and the teacher through giving feedback and grades. Fifth, following the same procedures as the second, third and fourth steps, other students were selected to present their home teams' results and report back to the class. The presenters' grades were calculated based 
on an average of the grades provided by the teacher, audience teams, and their home team, and were then recorded as their team grade. This team assessment system achieved a good balance between formative and summative assessment through the teacher and peers providing immediate feedback and assigning team grades. In addition, it particularly valued progress and effort by incorporating improvement points into assessment, that is, adjustments were made to previous team grades according to the extent of the improvement made at a particular time.

To sum up, this modified NHT strategy was used in order to have some teams present their work while not knowing in advance which teams would be selected, and to have one student represent his/her team while not knowing in advance who its representative would be. This technique thereby ensured positive interdependence and individual accountability was incorporated into teamwork and assessment, which enabled all the team members to feel motivated and obliged to learn, to help each other and to contribute to the team task, so that everyone was prepared and competent for presentations. In addition, formative assessment and improvement points were integrated into the use of the team grade which particularly recognized team progress, encouraged teams to compete with themselves rather than with others, and thus served as a motivating technique to foster perceived competence, team cooperation, and equal opportunities for success (see Ning (2011) for more details on tertiary EFL teaching using the CL approach).

The control group teacher followed the same regular way of teaching speaking skills adopted in the university. The traditional techniques used with the control group mainly involved teacher-dominated whole-class instruction, which focused on the accuracy of vocabulary and grammar, and the processing of texts lexically and syntactically. Peer interaction, language practice, and communicative fluency were not emphasized because teacher talk took up most of the class sessions. Discussion topics and learning tasks, which were carefully designed to suit students of different language levels within a cooperative team were also modified for use with the control group mostly in the form of direct instruction or occasionally traditional group work.

Traditional group work differed from CL teamwork mainly in four aspects. First, traditional groups were formed by putting several the nearest neighbors together on a random and temporary basis, while home teams with stable membership were used in the CL classroom. Second, traditional group work did not include two key elements of CL, that is, positive interdependence and individual accountability, which are essential for CL teamwork. Third, students in traditional groups worked together but volunteered to report on group work. It was mostly a small number of high-achievers who took the opportunity to speak. Sometimes no students would volunteer, so the teacher had to provide the answer himself. This formed a contrast with cooperative group work where everyone stood a chance of being selected as a team representative to present the results of their teamwork. Fourth, in traditional group work students were assessed individually, with the teacher as the sole assessor, while students in CL teams were assessed as a team, based on the opinion of both the teacher and students. So in the course evaluation, although it was the same for both groups that $70 \%$ of the final scores on the course came from the final examination at the end of the semester, the sources of the other $30 \%$ were different - it was individual grades on both class performance and assignments for the comparison group, while it was team grades for the intervention group.

All the classes were having the same number of hours of learning speaking skills during the time of the experiment.

\section{Instruments}

The study mainly used two research instruments. The first one was a speaking test used as a pre- test and a posttest to measure students' English-speaking performance. The test contains three tasks: talking about picture differences, reading a text aloud, and expressing one's opinion about a particular topic. The scoring rubric for the test provided a measure of the quality of the performance on the basis of five criteria: pronunciation, grammatical accuracy, vocabulary, fluency, and interactive communication on a five-rating scale (i.e., 1. Strongly Agree; 2 . Agree; 3. Not Sure; 4. Disagree; 5 . Strongly Disagree) based on the scales followed at Islamic Azad university in Iran (Ministry of Higher Education, 2011). The validity of a test is an important feature for a research instrument. An instrument is said to have validity if it measures exactly what it is supposed to measure (Gay, Mills, \& Airasian, 2009). All the items on the speaking test were reviewed by the researchers as self-validation. Then the items were given to three experts to ensure the content validity of the test. The experts 
were asked to validate and evaluate the test by completing a checklist for validating the English-speaking test. The results of the experts' evaluation of the test and the scoring rubric showed that all of the criteria used to assess the test on the five-point scale were viewed positively by the experts. The reliability of the speaking test used in this study was estimated by the test-retest method. It involved administering the same test twice to a group of students within the span of a few days (10 days) and calculating a correlation coefficient between the two sets of scores. The assumption was that the test takers would get the same scores on the first and the second administrations of the same test. This statistical method was adopted in order to obtain the reliability of the speaking test. The estimated reliability of the speaking test used in the current study was 0.85 measured through Cronbach's Alpha.

Another essential component to test reliability is that of inter-rater reliability. As it relates to the current study, inter-rater reliability is the degree of agreement between two scorers. If the level of reliability between the two scorers reaches the level of significance, this may indicate that the two scorers are fair in their scoring. In the current study, the correlation coefficients obtained for the two scorers were 0.910 and 0.914 , respectively, indicating quite high inter-rater reliability. Therefore, this test is reliable for experimentation and could be considered a valid research tool for measuring the sample's speaking test. A scoring rubric, adopted from the Ministry of Higher Education - Iran (2011), was used along with the scoring sheet for the purpose of grading. The grading of the speaking skills was based upon five criteria: (1) pronunciation (20\%), (2) grammatical accuracy (20\%), (3) vocabulary (20\%), (4) fluency (20\%), and (5) interactive communication (20\%).

The second instrument is a questionnaire that was used to measure students' motivation towards CL before and after the experiment. The measure of motivation used in this study was the LLOS (Language Learning Orientations Scale). The LLOS was developed by Dr Kimberly Noels (Noels, Pelletier, Clement, \& Vallerand, 2000) on the basis of self-determination theory. The LLOS consists of 42 items and is intended to measures six factors: intrinsic motivation (10 items), integrated regulation (eight items), identified regulation (six items), introjected regulation (seven items), external regulation (seven items), and amotivation (four items). All the items on the subscales apart from amotivation share the stem "I am learning English ..." Example items are “... because it's a great feeling to be able to use English" (intrinsic motivation), “... because it will enable me to better understand English speakers' life and culture” (integrated regulation), “... because I choose to be the kind of person who can speak English” (identified regulation), “... because I would feel ashamed if I couldn't speak to English speakers in English” (introjected regulation), “... because I want to complete an academic requirement” (external regulation), and “I don't know; I cannot come to understand why I am studying English” (amotivation).

A seven-point Likert scale was used in the questionnaire, ranging from one to seven (respectively representing "does not correspond at all" to "corresponds exactly") for scoring. The LLOS was already available in English. However, some minor changes and adjustments were made to the Persian translation of several items for a clearer understanding, and the researchers have reported these changes to Dr. Noels. The two sets of data, from the pre-test and the post-test, indicated good internal reliability for the LLOS. Cronbach's alpha coefficients for the total scale are 0.989 in the pre-test and 0.956 in the post-test. All six subscales had Cronbach's alphas above 0.85 .

\section{Data Collection Procedures}

Before the experiment started, an oral performance test and attitudinal questionnaire were administered to the students in the control and the experimental groups. After that, the actual experiment began. Students in the control group were taught through the traditional method of teaching speaking skills, while the students in the experimental group were taught using CL. Students in the experimental group were divided into six groups, each consisting of five students. However, the students were able to select the group members to work with on alternate weeks during the study period, i.e. three months. Throughout the group work, each member had to present a topic. Then each group discussed a chosen topic, exchanged ideas, helped each other, and shared knowledge. Each group member was assigned a role and responsibility that must be fulfilled if the group was to function effectively. Those roles were assigned to ensure interdependence. At the end of the study, post-tests of oral performance and students' motivation towards CL were given to the students.

\section{Data analysis}


To find out the effect of CL on speaking competence, descriptive statistics including mean scores and standard deviations of the pre-test and post-test were used. Inferential analysis was used to find out if any significant differences were found between the control and experimental groups in both the pre-test and post-test. A normality test was used to determine if a sample or any group of data fits a standard normal distribution. Inferential analysis was used to find out if any significant differences were found between the control group and experimental group in both the pre- and post-tests. However, statistical significance does not tell us the most important thing about the size of the effect. One way to overcome this confusion is to report the effect size, which is simply a way of quantifying the size of the difference between two groups ((Thalheimer \& Cook, 2002). It is particularly valuable for quantifying the effectiveness of a particular intervention, relative to some comparison (Coe, 2002). Since the "d" value is not directly provided by SPSS, Pallant (2007) recommends a very useful website that provides a quick and easy way to calculate Cohen's $d$ at http://www.uccs.edu/ faculty/ lbecker/. In this study, the effect size was reported using the effect size "d" as proposed by Cohen (1992). The justification for using Cohen's "d" stems from "its burgeoning popularity" among large numbers of published studies (Thalheimer \& Cook, 2002, p.2). Additionally, Cohen's "d" has a benchmark by which a researcher can compare the effect size of an experiment to a well-known benchmark (ibid). Guidelines for interpreting the $d$ value vary according to different academic fields and research purposes. According to Cohen (1988), effect sizes of around 0.2 are small, 0.5 moderate, and 0.8 large. However, Slavin (2014) considered effect sizes over 0.25 to be educationally meaningful. Recently, based on a synthesis of over 800 meta-analyses relating to achievement in the field of education, Hattie (2009) found 0.4 to be the average effect size for educational interventions, suggesting that an effect size above 0.4 is above average and therefore worth noting when evaluating educational outcomes. Since Hattie's guideline is based on a large number of educational studies, it is considered the most appropriate for this research.

Moreover, the data collected for analysis in this research comprised pre-test and post-test scores on the LLOS in six areas: intrinsic motivation, integrated regulation, identified regulation, introjected regulation, external regulation, and amotivation. The 25th version of SPSS was used to conduct data analysis on the effects of the adapted CL method versus traditional instruction on each of these areas. Since the two groups showed some differences on the pre-test, a one-way analysis of covariance (ANCOVA) was used with pre-test scores as the covariate, post-test scores as the dependent variable, and type of group as the fixed factor. This ANCOVA procedure is able to hold constant any differences in the pre-test scores and evaluates the post-test differences between groups (Pallant 2007).

To sum up, the data in this research were analyzed by means of a range of statistical techniques, which include paired-samples t-tests, effect sizes, and one-way ANCOVAs. It is believed that the combined use of a variety of analysis techniques enables the researcher to have a clearer picture about the phenomenon of interest (Thalheimer, \& Cook, 2002). Therefore, it contributes to obtaining more valid and reliable results, and reduces the possibility of biased findings due to the use of a single statistical analysis.

\section{Results}

The main results are presented and displayed based on the questions of the study. The data obtained from the pre-/post-test of the oral performances and the motivation were analyzed and interpreted using the Statistical Package for the Social Sciences (SPSS). The results were used to answer the research questions.

\section{Results for the Normality Test}

The $p$ values under the Sig. column in Table 1 determine whether the distributions were normal or not. A $p$ value greater than .05 shows a normal distribution, while a $p$ value lower than .05 demonstrates that the distribution has not been normal. Since all the $p$ values in Table 1 were larger than .05 , it could be concluded that the distributions of scores for the pre-test, post-test, and questionnaire obtained from both groups had been normal. It is thus safe to proceed with parametric tests (i.e. Independent and paired samples t-tests and one-way ANCOVA in this case) and make further comparisons between the participating groups. 
Table 1

One-Sample Kolmogorov-Smirnov Test (Groups'Pre-tests, Post-tests, and Questionnaire)

\begin{tabular}{lccc}
\hline & \multicolumn{3}{c}{ Kolmogorov-Smirnov } \\
\cline { 2 - 4 } & Statistic & df & Sig. \\
\hline Exp. Speaking pre & .14 & 45 & .094 \\
Exp. Speaking post & .27 & 45 & .098 \\
Cont. Speaking pre & .27 & 45 & .112 \\
Cont. Speaking post & .34 & 45 & .090 \\
Exp. Motivation Questionnaire pre & .18 & 45 & .187 \\
Exp. Motivation Questionnaire post & .22 & 45 & .086 \\
Cont. Motivation Questionnaire pre & .21 & 45 & .772 \\
Cont. Motivation Questionnaire post & .17 & 45 & .183 \\
\hline
\end{tabular}

\section{Results for Research Question One}

As pointed out above, the first research question of the study was: Does cooperative learning have any significant effect on developing students' speaking skills? The overall average mean score of the experimental group on the pre-test was 59.13 with a standard deviation of 2.94, while that of the control group was 58.46 with a standard deviation of 2.61. As shown in Table 2, the speaking performance mean scores of the experimental group were all similar to the scores of the control group. Relative to each other, both the control and the experimental groups were similar in their speaking skills before carrying out the experiment.

Table 2

Descriptive Statistics for Comparing the Experimental and Control Groups in the Pre-test of Speaking Performance

\begin{tabular}{llllcl}
\hline & \multicolumn{1}{c}{ Groups } & N & Mean & Std. Deviation & Std. Error Mean \\
\hline \multirow{2}{*}{ Pre-test } & Experimental group & 45 & 59.13 & 2.94 & .43 \\
\cline { 2 - 6 } & Control group & 45 & 58.46 & 2.61 & .39 \\
\hline
\end{tabular}

In order to find out whether this difference between the pre-test scores of the EG and CG learners was statistically significant or not, the following t-test table had to be checked:

Table 3

Independent Samples T-Test of Experimental and Control Groups in the Pre-test

\begin{tabular}{|c|c|c|c|c|c|c|c|c|}
\hline & \multirow{2}{*}{$\mathbf{F}$} & \multicolumn{2}{|c|}{$\begin{array}{c}\text { Levene's Test for } \\
\text { Equality of Variances }\end{array}$} & \multicolumn{5}{|c|}{ t-test for Equality of Means } \\
\hline & & Sig. & $\mathrm{t}$ & $\mathrm{df}$ & $\begin{array}{c}\text { Sig. } \\
\text { (2-tailed) }\end{array}$ & $\begin{array}{c}\text { Mean } \\
\text { Difference }\end{array}$ & $\begin{array}{l}\text { Std. Error } \\
\text { Difference }\end{array}$ & \\
\hline \multirow[t]{2}{*}{ Pre-test } & Equal variances assumed & .90 & .34 & 1.13 & 88 & .259 & .66 & .58 \\
\hline & Equal variances not assumed & & & 1.13 & 86.807 & .259 & .66 & .58 \\
\hline
\end{tabular}

Table 3 demonstrates a lack of any significant statistical difference at the confidence level of $\alpha=0.05$ between the students in the control and experimental groups before the experiment. The p-value $.259>0.05$ reveals that there is no significant difference between the mean scores of the two groups on the pre-test $(\alpha=0.05)$. Thus, it is evident that the two groups had the same level of English-speaking competence before the experiment. 
Table 4

Descriptive Statistics for Comparing the Experimental and Control Groups in the Post-test of Speaking Performance

\begin{tabular}{lllccc}
\hline & \multicolumn{1}{c}{ Groups } & N & Mean & Std. Deviation & Std. Error Mean \\
\hline \multirow{2}{*}{ Post-test } & Experimental group & 45 & 63.48 & 7.63 & 1.13 \\
& Control group & 45 & 58.91 & 2.32 & .34 \\
\hline
\end{tabular}

However, the mean score of the experimental group on the post-test was 63.48 with a standard deviation of 7.63 while that of the control group on the post-test was 58.91 with a standard deviation of 2.32. Table 4 presents the speaking competence mean scores of the experimental group in the post-test which were all higher than the scores of the control group. This result provides confirmatory evidence of a noticeable increase in the post-test mean score of speaking skill in favor of the experimental group.

To ensure that the difference between the mean scores of the control and experimental groups in the post-test were statistically significant, an independent sample t- test was run. Table 5 shows that there is a statistically significant difference in the post-test between the experimental and control groups in of favor of the experimental group with $\mathrm{t}$ - value $=3.84, \mathrm{p}=.000<0.05$.

Table 5

Independent Samples T-Test of Experimental and Control Groups in the Post-test

\begin{tabular}{|c|c|c|c|c|c|c|c|c|}
\hline & \multirow{2}{*}{$\mathbf{F}$} & \multicolumn{2}{|c|}{$\begin{array}{c}\text { Levene's Test for } \\
\text { Equality of Variances }\end{array}$} & \multicolumn{5}{|c|}{ t-test for Equality of Means } \\
\hline & & Sig. & $\mathbf{t}$ & df & $\begin{array}{c}\text { Sig. } \\
\text { (2-tailed) }\end{array}$ & $\begin{array}{c}\text { Mean } \\
\text { Difference }\end{array}$ & $\begin{array}{l}\text { Std. Error } \\
\text { Difference }\end{array}$ & \\
\hline \multirow[t]{2}{*}{ Post-test } & Equal variances assumed & 40.08 & .000 & 3.84 & 88 & .000 & 4.57 & 1.18 \\
\hline & Equal variances not assumed & & & 3.84 & 52.08 & .000 & 4.57 & 1.18 \\
\hline
\end{tabular}

In order to find out whether the difference between the pre-test and post-test scores of learners in each group (i.e., EG and CG) was statistically significant or not, the following $t$-test was run:

Table 6

Results of the Paired-Samples T-Test Comparing Pre-test and Post-test Scores of the EG and CG

\begin{tabular}{llcccccc}
\hline & & Mean & Std. Deviation & Std. Error Mean & t & df & Sig. (2-tailed) \\
\hline Pair 1 & Exp. Post - Exp. Pre & 4.35 & 6.16 & .91 & 4.74 & 44 & .000 \\
Pair 2 & Cont. Post - Cont. Pre & .44 & 1.51 & .22 & 1.96 & 44 & .056 \\
\hline
\end{tabular}

Table 6 revealed that there was a statistically significant difference between the pre-test $(M=59.13, S D=2.94)$ and post-test $(\mathrm{M}=63.48, \mathrm{SD}=7.63)$ scores of the EG learners since the $\mathrm{p}$ value under the Sig, (2-tailed) column was smaller than the significance level (i.e. .000<.05). This indicates that the treatment (Using cooperative learning) was effective as far as the speaking skills of the Iranian EFL learners were concerned. Regarding the control group, which received traditional instruction, no significant difference was found since the Sig, (2-tailed) column was a little higher than the significance level (i.e. .056 .05). Thus, it can be concluded that cooperative learning was more effective than traditional instruction.

To further compare differences between the experimental group and control group and to find out the effect of CL on students' speaking competence, the overall post-test scores of the two groups were compared. The results revealed an effect size of 0.81 which can be interpreted as a large effect of the independent variable (CL) on the dependent variable (speaking skill).

\section{Results for Research Question Two}

The second research question of the study was: What is the effectiveness of the CL approach for improving students' learning motivation, compared with traditional instruction, in English teaching at a university in 
Iran? The results obtained from the analysis of the scores on the LLOS are summarized in Table 7, which includes mean scores, standard deviations, effect sizes, and $\mathrm{p}$ values from paired-samples t-tests within each group and the ANCOVAs, in each of the six aspects of the LLOS.

Table 7

Summary of Results on The LLOS for the Experimental and Control Groups

\begin{tabular}{|c|c|c|c|c|c|c|c|}
\hline $\begin{array}{c}\text { LLOS } \\
\text { (42 items) }\end{array}$ & Group & Pre/Post & Mean & SD & Sig.t-test & $\begin{array}{c}\text { Effect } \\
\text { size }\end{array}$ & $\begin{array}{c}\text { Sig. } \\
\text { ANCOVA }\end{array}$ \\
\hline \multirow{4}{*}{$\begin{array}{l}\text { Intrinsic } \\
\text { motivation } \\
(10 \text { items) }\end{array}$} & \multirow{2}{*}{ Exp. } & Pre & 35.86 & 8.98 & 0.00 & 0.49 & 0.05 \\
\hline & & Post & 40.68 & 10.89 & & & \\
\hline & \multirow{2}{*}{ Cont. } & Pre & 35.67 & 11.02 & 0.008 & 0.19 & \\
\hline & & Post & 37.49 & 10.26 & & & \\
\hline \multirow{4}{*}{$\begin{array}{l}\text { Integrated } \\
\text { motivation } \\
\text { (8 items) }\end{array}$} & \multirow{2}{*}{ Exp. } & Pre & 27.98 & 5.34 & 0.07 & 0.21 & 0.79 \\
\hline & & Post & 29.36 & 7.09 & & & \\
\hline & \multirow{2}{*}{ Cont. } & Pre & 27.96 & 9.14 & 0.07 & 0.14 & \\
\hline & & Post & 29.39 & 8.29 & & & \\
\hline \multirow{4}{*}{$\begin{array}{l}\text { Identified } \\
\text { motivation } \\
\text { (6 items) }\end{array}$} & \multirow{2}{*}{ Exp } & Pre & 26.56 & 5.36 & 0.03 & 0.18 & 0.69 \\
\hline & & Post & 27.59 & 5.96 & & & \\
\hline & \multirow{2}{*}{ Cont. } & Pre & 28.11 & 5.69 & 0.29 & 0.15 & \\
\hline & & Post & 29.31 & 5.61 & & & \\
\hline \multirow{4}{*}{$\begin{array}{l}\text { Introjected } \\
\text { motivation } \\
\text { (7 items) }\end{array}$} & \multirow{2}{*}{ Exp. } & Pre & 23.14 & 6.02 & 0.08 & 0.19 & 0.89 \\
\hline & & Post & 24.16 & 6.94 & & & \\
\hline & \multirow{2}{*}{ Cont. } & Pre & 23.21 & 7.34 & 0.16 & 0.17 & \\
\hline & & Post & 24.39 & 6.98 & & & \\
\hline \multirow{4}{*}{$\begin{array}{l}\text { External } \\
\text { motivation } \\
(7 \text { items })\end{array}$} & \multirow{2}{*}{ Exp. } & Pre & 34.36 & 6.29 & 0.42 & 0.08 & 0.13 \\
\hline & & Post & 34.96 & 6.48 & & & \\
\hline & \multirow{2}{*}{ Cont. } & Pre & 30.94 & 7.09 & 0.45 & -0.07 & \\
\hline & & Post & 29.86 & 7.19 & & & \\
\hline \multirow{4}{*}{$\begin{array}{l}\text { Amotivation } \\
\text { (4 items) }\end{array}$} & \multirow{2}{*}{ Exp. } & Pre & 24.02 & 4.18 & 0.16 & 0.16 & 0.71 \\
\hline & & Post & 24.59 & 3.06 & & & \\
\hline & \multirow{2}{*}{ Cont. } & Pre & 21.96 & 4.18 & 0.19 & 0.24 & \\
\hline & & Post & 22.88 & 3.96 & & & \\
\hline
\end{tabular}

In the area of intrinsic motivation, results of paired-samples t-tests showed that the experimental group [ $\mathrm{t}(44)$ $=4.36]$ increased significantly from pre-test to post-test, but the control group [ $\mathrm{t}(44)=1.91]$ did not. According to Hattie's (2009) guidelines, the effect size (of 0.49) for the experimental group was above average, but this was not the case for the experimental group. The Sig. ANCOVA $=0.05$ indicated a significant difference on the posttest between the two groups after adjusting for pre-test scores. In the other five areas of integrated regulation: identified motivation, introjected regulation, external regulation, and amotivation, results of ANCOVAs showed no significant difference between the two groups. Although effect sizes for both groups were below the average, results of $t$-tests indicated that the experimental group [ $t(44)=2.10$ ] improved significantly in the area of identified regulation, but the control group [ $\mathrm{t}(44)=1.06$ ] did not. In the other four areas of integrated regulation, introjected regulation, external regulation, and amotivation, both t-tests and effect sizes showed no significant improvements for both the experimental group and the control group.

To sum up, the overall findings on the LLOS indicated that participants in the intervention group significantly improved their intrinsic motivation and identified regulation from pre-test to post-test, whereas the comparison group did not show significant improvements in any areas on the LLOS. However, according to the results of the ANCOVAs, it was only in the area of intrinsic motivation that the improvements of the two groups differed significantly. These findings were further supported by effect size statistics. The only effect size that was above average occurred with the intervention group in the area of intrinsic motivation. 


\section{Discussion}

The findings of this study reveal positive outcomes both in terms of Iranian EFL students' oral performance and motivation towards the use of CL as a new instructional method in English speaking classrooms in Iran. The findings of the study are discussed based on the two research questions of the study.

The first research question sought to find out whether CL has any effect on improving the speaking skills of the Iranian university EFL students in the sample. The performance of the experimental group after being exposed to CL activities showed a significant difference between the results of the experimental and control groups. The experimental group showed a positive score difference and/or improvement after the CL method was introduced as a teaching technique in speaking skill classrooms; whereas the performance of the control group, which was exposed to the traditional method for learning speaking skills, showed no significant difference between the results of the pre-test and post-tests of speaking skill. This could be attributed to the fact that the traditional teaching method in Iran is teacher-based, in which less opportunity is given to students to practice their speaking skills in classrooms. This finding is consistent with the findings of Ning and Hornby (2010) that showed significant differences in scores between the pre-test and post- tests in favor of the experimental group that was provided with CL treatment in listening, speaking, reading, writing, and vocabulary. The results proved that CL is essential for maximizing speaking proficiency. Along similar lines, the finding of Johnson and Johnson (2003) supported the claim that CL resulted in higher individual achievement. The findings of this study provide confirmatory evidence in support of the results gained by Talebi and Sobhani (2012), Pattanpichet (2011), Ning (2011), and Yang (2005), which asserted that the CL approach can contribute to the improvement of students' speaking proficiency. A closer look at the data of the current study indicates that CL is highly recommended over the traditional method in teaching English speaking skills at the university level in Iran. The study signifies the possibility of implementing the CL method in Iranian schools and, thus, Iranian EFL learners can increase their communicative ability.

In other words, in a comfortable context such as cooperative learning, the students in the experimental group were able to demonstrate higher oral classroom participation, which is related to their statistically significant gain in language proficiency (Soleimani \& Khosravi, 2018).

Similarly, Tuncel (2006), who used supplementary communicative and authentic materials with his subjects, suggested "The addition of a communicative element leads to higher students' achievement in measuring their test scores, and later in their specialist studies" (p.2).

Based on the results of the present study, there was no statistic significant difference between the control group's pre-test and post-test. One can argue that this was expected, since the control group most probably had no opportunities to do communicative activities. Practitioners (Namaziandost \& Rahimi Esfahani, 2018; Woods, 2013) argue that traditional methods are untrustworthy and inadequate because they do not help students use the target language as it is used in real-life situations, where they need to communicate effectively with others.

Since studying according to the traditional methods did not help students to cope with the target language in what Zhang, Peng, and Sun (2017) would describe as its normal communicative use, the control group could not improve their speaking skills. In the traditional classroom, much of the students' time is devoted to learning and memorizing language forms.

Based on the results, cooperative learning had a positive effect on the student's speaking skills. The big differences between the experimental group and the control group could be attributed to many reasons; firstly, during the experiment, the group work used for the experimental group provided the students with opportunities to speak for most of the English period. On the other hand, the control group followed the traditional method. Secondly, because of the Kagan's cooperative structures in the experimental group, all of the students were encouraged to speak and tried to be active so they became more confident and more willing to speak; but in the control group, students who studied in the traditional classroom did not have the opportunity to be responsible for their own learning and they were not very active in the class. Finally, such a student-centered teaching method helped improve the student's' oral communicative competence of the target language because it created a friendlier and more supportive learning environment within which students had more opportunities and enjoyed the freedom to practice the target language. 
The significant gains of the experimental group on the interaction-based task supported Brown's (2007) and Kagan's (1995) views that cooperative learning was actually a practice that could put the communicative approach into action. Such findings were congruent with Woods's (2013) claim that cooperative learning was considered the best instructional format for enhancing learner's communicative competence. Yu (2004) stated in his research that one of the obstacles that hinders CL in the class is the classroom size; if the classroom size is big, students may get fewer opportunities to practice English.

The second research question sought to determine whether CL could improve students' attitudes more than the conventional method. The major finding on the LLOS is that the experimental group, which was taught using the CL approach, improved on intrinsic motivation more than the comparison group instructed by traditional methods, although the difference was only marginally statistically significant. There were no statistically significant differences between the two groups in the other five aspects of motivation. These findings and the possible reasons for them are discussed below.

The finding that the CL approach was superior to traditional instruction in enhancing learners' intrinsic motivation supports the widely accepted view that CL generates higher levels of intrinsic motivation (Jacobs \& Goh 2007; Johnson \& Johnson 2003; Kagan \& Kagan 2009; Soleimani \& Khosravi, 2018). Supportive evidence for this was also revealed in some studies (Derwing \& Munro, 2013) that indicated that, when compared with traditional teaching, CL was more likely to improve students' positive attitudes towards EFL learning, which may facilitate students' interest and intrinsic motivation to learn. The positive link between CL and intrinsic motivation may be primarily attributed to the ability of CL to facilitate a supportive and non-threatening learning atmosphere where students find it fun and enjoyable to learn and, thus, are intrinsically motivated to achieve goals.

In this research, there are four possible reasons for the finding of increased intrinsic motivation. These are closely associated with the satisfaction of three basic psychological needs - competence, autonomy, and relatedness. First, students in the CL group had opportunities to use English as a communicative tool when working on team tasks. When students found they could successfully use the English language to complete a task or do something real and meaningful, they may have experienced positive feelings caused by meeting challenges and a high level of satisfaction from the outcomes of their learning. This experience could have satisfied their need for competence and generated a sense of accomplishment, which further stimulated their desire and interest to learn and try out the language. Second, students were allowed more ownership and control over their learning in the CL group, for instance, by choosing their topics, sub-tasks, or ways of completing teamwork, assigning individual accountability to team members, or assessing their learning outcomes through self and peer grading. Empowering students and increasing their autonomy in learning may also have been conducive to the enhancement of intrinsic motivation. Third, intrinsic motivation tends to result from meaningful feedback relevant to the extent to which students competently complete their current tasks (Johnson \& Johnson, 2003). In the CL group, meaningful feedback was provided by peers and the teacher immediately after the selected teams had presented their work. Through feedback from others, students should have gotten a clear picture about what their strengths and weaknesses were and how they could improve their work, which could have led to the feeling that their work and effort were valued and recognized by the teacher and their peers. This may have facilitated their intrinsic motivation for setting up new attainable goals and getting engaged in learning tasks. Fourth, it is believed that when students realize that their personal achievement is important and beneficial to peers they feel more positively related to others and, thus, intrinsically motivated to accomplish more (Gagne \& Deci, 2005; Law, 2011). In their research, students in the CL classroom were clear that everyone stood a chance of representing their home team and that their success would benefit other teammates. This could have facilitated teammates' enthusiasm for positive interpersonal support and further promoted students' intrinsic motivation to improve and achieve.

In brief, this research suggests that CL may have an important role to play in tertiary English teaching in Iran because of the findings that CL was better than traditional teaching in improving learners' intrinsic motivation. Even though intrinsic motivation is considered a critical factor for enjoyable and successful language learning in the long run, it is particularly hard to attain in the foreign language learning context (Carreira 2011), and typically declines among tertiary foreign language learners (Busser \& Walter 2013; Namaziandost \& Ahmadi, 2019), this study may be of considerable interest to foreign language teachers who work in tertiary education. 


\section{Conclusion}

In summary, CL as a student-centered approach improves the speaking skills and motivation among the students in this study. Therefore, teachers in schools, especially teachers who teach English speaking skills need to be aware of the benefits and importance of CL. There are positive changes taking place when teachers change their teaching methods towards a more student-centered approach. Teachers need to master the types of speaking techniques to be used and plan how to implement them with the CL method. Therefore, teachers are encouraged to practice this method regularly and effectively. There is overwhelming evidence corroborating the notion that CL has a positive effect on the formation of positive motivation towards speaking among students. Finally, and on the basis of the evidence provided by this research, it seems quite reasonable to state that CL has many benefits, such as improving speaking skills and motivation. Although, there is no 'perfect methodology', CL is an instructional method that is effective in enhancing the acquisition of English-speaking skills and improving students' motivation.

However, several limitations in this research may affect the validity or generalizability of its results. Considering these limitations, some recommendations include:

1. The number of participants was restricted only to 90 students. So, the findings must be generalized and used with caution. Future studies should include more participants.

2. Only male students were included in this study, therefore; the results may not be generalizable to female students. It is recommended that both genders be considered in future researches.

3. The LLOS is purely a self-report instrument, which provides a picture of respondents' beliefs about themselves and may not provide an accurate reflection of their motivation levels. In other words, they may select responses that are assumed to be more socially acceptable even if they are not actually the truth (Gay, Mills, \& Airasian 2009). A recommendation for future research is to employ mixed methods research designs including both quantitative data (e.g. from tests or surveys) and qualitative data (e.g. from interviews with students or teachers) in a single study. This approach to research is considered conducive to understanding research settings both broadly (i.e. from quantitative data) and deeply (i.e. from qualitative data). The indepth qualitative data obtained from interviews with participants may partly remedy the possible effects of the response set existing in self-report instruments.

4. The foregoing discussion implies that not only does CL improve speaking skills, but can strongly and indirectly enhance students' motivation. The skill that has been investigated in this study was speaking. Hence, future research should also focus on whether the same results will be yielded by investigating the impact of CL on other English skills such as writing and reading.

5. Future research should also replicate the same study in all other disciplines and in urban areas or again in rural areas.

6. Based on the findings of the current study, it is recommended that English teachers should adopt CL as an effective learning method in order to improve students' speaking performance. Finally, in respect of the findings and the other empirical findings, we suggest that CL should be part of the daily instructional methods used in all the teacher training programmes in Iran. It is the responsibility of teachers to be aware of the various learning preferences that students bring to the classroom and to try to take full advantage of them during the daily teaching and learning process.

7. The application of the CL method should be tested at different levels of education, such as elementary, secondary, and higher education.

8. This study only lasted for one term; therefore, prospective researchers should take a longer time to cross validate the results of the current study.

\section{References}

Alharby, H. A. (2015). Improving students' English-speaking proficiency in Saudi public schools. International Journal of Instruction, 8(1), 105-115.

Al-Sohbani, Y. A. (2013). An exploration of English language teaching pedagogy in secondary Yemeni education: A case study. International journal of English Language \& Translation Studies, 1(3), 40-55.

Al-Tamimi, N. O. M., \& Attamimi, R. A. (2014). Effectiveness of cooperative learning inenhancing speaking 
skills and attitudes towards learning English. International Journal of Linguistics, 6(4), 27-45. https://doi. org/10.5296/ijl.v6i4.6114

Amedu, O. I., \& Gudi, K. C. (2017). Attitude of students towards cooperative learning in some selected secondary schools in Nasarawa state. Journal of Education and Practice, 8(10), 29-34.

Bagheri, M. S., Dabaghmanesh, T., \& Zamanian, M. (2013). The Effect of cooperative learning approach on Iranian EFL students' achievement among different majors in general English course. International Journal of Linguistics, 5(6), 1-11.

Bolukbas,F., Keskin, F., \& Polat, M.(2011). The effectiveness of cooperative learning in the reading comprehension skills in Turkish as a foreign language. The Turkish Online Journal of Educational Technology, 10(4), 330-335.

Brown, H. D. (2007). Teaching by principles (3rd ed.). London, UK: Longman.

Busser, V., \& Walter, C. (2013). Foreign language learning motivation in higher education: A longitudinal study of motivational changes and their causes. The Modern Language Journal, 97, 435-456. https://doi.org/10.1111/ j.1540-4781.2013.12004.x

Carreira, J. M. (2011). Relationship between motivation for learning EFL and intrinsic motivation for learning in general among Japanese elementary school students. System 39, 90-102.

Cohen, J. (1988). Statistical Power Analysis for the Behavioral Sciences (2nd ed.). Hillsdale, NJ: Lawrence Erlbaum.

Derwing, T. M., \& Munro, M. J. (2013). The development of L2 oral language skills in two L1 groups: A 7-year study. Language Learning, 63(2), 163-185. https://doi.org/10.1111/lang.12000

Gagne, M., \& Deci, E. L. (2005). Self-determination theory and work motivation. Journal of Organizational Behavior, 26, 331-362. https://doi.org/10.1002/job.322

Gay, L. R., Mills, G. E., \& Airasian, P. (2009). Educational research: Competencies for analysis and applications (9th ed.). London, UK: Pearson Education.

Harmer, J. (2008). How to teach English. Essex, UK: Pearson.

Hattie, J. (2009). Visible learning: A synthesis of over 800 Meta-analyses relating to achievement. London, UK: Routledge.

Hedge, T. (2008). Teaching and learning in the language classroom. Oxford, UK: Oxford University Press.

Hernández, T., \& Boero, P. (2018). Explicit intervention for pragmatic development during short-term study abroad: An examination of learner request production and cognition. Foreign Language Annals, 51(2), 389410. https://doi.org/10.1111/flan.12334

Johnson, D. W., \& Johnson, R. T. (2003). Student motivation in co-operative groups: Social interdependence theory. In R. M. Gillies \& A. F. Ashman (Eds.), Cooperative learning: The social and intellectual outcomes of learning in groups (pp. 137-176). London. UK: Routledge.

Johnson, D. W., Johnson, R. T., \& Smith, K. A. (2006). Active learning: Cooperation in the college classroom. Edina, $\mathrm{MN}$ : Interaction Book Company.

Kagan, S. (1995). When we talk: Cooperative learning in the elementary ESL classroom. Elementary Education Newsletter, 17(2), $1-6$.

Kagan, S., \& Kagan, M. (2009). Kagan cooperative learning. San Clemente, CA: Kagan Publishing.

Kandasamy, C., \& Habil, H. (2018). Exploring cooperative learning method to enhance speaking skills among school students. LSP International Journal, 5(2), 1-16. https://doi.org/10.11113/lspi.v5n2.59

Kayi, H. (2006). Teaching speaking: Activities to promote speaking in a second language. TESOL, 11(12), 1-6.

Keshmirshekan, M. H., Namaziandost, E., \& Pournorouz, M. (2019). The impacts of creative writing activities on Iranian EFL learners' progress in writing, writing dispositions: Focus on attitude to English course. International Journal of Educational Research, 3(9), 12-22.

Kumaran, S. (2017). Benefits and shortcomings of role-play as a speaking activity in English language classrooms. The English Teacher, 39(1), 72-93.

Law, Y. (2011). The effects of cooperative learning on enhancing Hong Kong 5th graders' achievement goals, autonomous motivation and reading proficiency. Journal of Research in Reading, 34(4), 402-425. https://doi. org/10.1111/j.1467-9817.2010.01445.x

Lazaraton, A. (2014). Second language speaking. In M. Celce-Murcia, D. Brinton \& M. Snow (Eds.), Teaching English as a second or foreign language (4th ed., pp. 106-120). Boston, MA: National Geographic Learning.

Leong, M., \& Ahmadi, S. M. (2017). An analysis of factors influencing learners' English-speaking skill. International Journal of Research in English Education, 6(2) 34-41.

Mackey, A. (2007). The conversational interaction in second language acquisition. Oxford, UK: Oxford University Press.

Metruk, R. (2018). Researching speaking. Teaching and assessment. Olomouc, Czech Republic: Palacký University 
Olomouc.

Ministry of Higher Education. (2011). Laws and regulation and rules of higher education and scientific research. Tehran, Iran: Islamic Republic of Iran.

Mishan, F., \& Timmis, I. (2015). Materials development for TESOL. Edinburgh, UK: Edinburgh University Press Ltd.

Namaziandost, E., \& Ahmadi, S. (2019). The assessment of oral proficiency through holistic and analytic techniques of scoring: A comparative study. Applied Linguistics Research Journal, 3(2), 70-82. http://doi. org/10.14744/alrj.2019.83792

Namaziandost, E., Abdi Saray, A., \& Rahimi Esfahani, F. (2018). The effect of writing practice on improving speaking skill among pre-intermediate EFL learners. Theory and Practice in Language Studies, 8(1), 16901697. http://dx.doi.org/10.17507/tpls.0812.16

Namaziandost, E., Abedi, P., \& Nasri, M. (2019). The role of gender in the accuracy and fluency of Iranian upperintermediate EFL learners' L2 oral productions. Journal of Applied Linguistics and Language Research, 6(3), 110-123.

Namaziandost, E., Nasri, M., \& Rahimi Esfahani, F. (2019). Pedagogical efficacy of experience-based learning strategies for improving the speaking fluency of upper-intermediate male and female Iranian EFL students. International Journal of Research in English Education, 4(2), 29-41.

Namaziandost, E., \& Rahimi Esfahani, F., (2018). The impact of writing practices on enhancing productive skills among pre-intermediate EFL learners. Asean Journal of Teaching and Learning in Higher Education, 10(1), 6180.

Namaziandost, E., Rahimi Esfahani, F., Nasri, M., \& Mirshekaran, R. (2018). The effect of gallery walk technique on pre-intermediate EFL learners' speaking skill. Language Teaching Research Quarterly, 8, 1-15.

Nasri, M., \& Biria, R. (2017). Integrating multiple and focused strategies for improving reading comprehension and 12 lexical development of Iranian intermediate EFL learners. International Journal of Applied Linguistics \& English Literature, 6(1), 311-321.http://dx.doi.org/10.7575/aiac.ijalel.v.6n.1p.311

Nasri, M., Namaziandost, E., \& Akbari, S. (2019). Impact of pictorial cues on speaking fluency and accuracy among Iranian pre-intermediate EF learners. International Journal of English Language and Literature Studies, 8(3), 99-109. http://dx.doi.org/10.18488/journal.23.2019.83.99.109

Ning, H. (2011). Adapting cooperative learning in tertiary ELT. ELT Journal, 65(1), 60-70. http://doi.org/10.1093/ elt/ccq021

Ning H., \& Hornby, G. (2010). The effectiveness of cooperative learning in teaching English to Chinese tertiary learner. Effective Education, 2(2), 99-116. https://doi.org/10.1080/19415532.2010.522792

Noels, K. A., L. G. Pelletier, R. Clement, \& R. J. Vallerand. (2000). Why are you learning a second language? Motivational orientations and self-determination theory. Language Learning, 50, 57-85. https://doi. org/10.1111/0023-8333.00111

Omer, N., \& Attamimi, R. (2014). Effectiveness of cooperative learning in enhancing speaking skills and attitudes towards learning English. International Journal of Linguistics, 6(4), 27-42. https://doi.org/10.5296/ ijl.v6i4.6114

Pallant, J. (2007). SPSS survival manual: A step by step guide to data analysis using SPSS version 15 (3rd ed.). Maidenhead, UK: Open University Press.

Pattanpichet, F. (2011). The effects of using collaborative learning to enhance students' English-speaking achievement. Journal of College Teaching \& Learning, 8(11), 1-10. https://doi.org/10.19030/tlc.v8i11.6502

Pattanpichet, F., \& Chinaokul, S. (2011). Competencies needs in oral communication in English among Thai undergraduate public relation students: A substantial gap between expectation and reality. RELC Journal, 42(2), 187- 202. https://doi.org/10.1177/0033688211401253

Richards, J., C. (2008). Teaching listening and speaking. Cambridge, UK: Cambridge University Press.

Russell, V. (2018). Web-based pragmatics resources: Techniques and strategies for teaching L2 Spanish pragmatics to English speakers. In D. Dumitrescu \& P. Andueza (Eds.), L2 Spanish pragmatics: From research to teaching (Series: Advances in Spanish Language Teaching). New York, NY: Routledge.

Shantha, S., \& Mekala, S. (2017). The role of oral communicative tasks (OCT) in developing the spoken proficiency of engineering students. Advances in Language and Literacy Studies, 8(2), 161-169. http://dx.doi.org/10.7575/aiac.alls.v.8n.2p.161

Slavin, R. E. (2014). Cooperative learning and academic achievement: Why does groupwork work? Anales de Psicologia, 30(3), 785-791. https://doi.org/10.6018/analesps.30.3.201201

Soleimani, H., \& Khosravi, A. (2018). The effect of Kagan's cooperative structures on speaking skill of Iranian EFL learners. International Journal of English Language \& Translation Studies, 6(1). 20-31. 
Sühendan, E. R., \& Bengü, A. A. (2014). The attitudes of students towards cooperative learning in ELT classes. International Online Journal of Education and Teaching, 1(2), 31-45.

Tahmasbi, S., Hashemifardnia, A., \& Namaziandost, E. (2019). Standard English or world Englishes: Issues of ownership and preference. Journal of Teaching English Language Studies, 7(3), 83-98.

Talebi, F., \& Sobhani, A. (2012). The impacts of cooperative learning on oral proficiency. Mediterranean Journal of Social Sciences, 3(3), 75-79. https://doi.org/10.5901/mjss.2012.v3n3p75

Tesfamichael, W. (2017). Students' attitudes towards cooperative learning in EFL writing class. Arabic Language, Literature \& Culture, 2(3), 60-68. https://doi.org/10.11648/j.allc.20170203.12

Thalheimer, W., \& Cook, S. (2002). How to calculate effect sizes from published research articles: A simplified methodology. Retrieved from http://work-learning.com/effect_sizes.htm.

Thornbury, S. (2005). How to teach speaking. Harlow, UK: Longman.

Tuncel, E. (2006). An evaluative of the relationship between instructional differences and learning outcomes: A survey-based and experimental study of a more communicative approach to language teaching in a traditional setting. Dissertation Abstract International, 67(02), 483 (UMI No. 824132).

Ur, P. (2012). A course in English language teaching. Cambridge, UK: Cambridge University Press.

Woods, P. (Ed.). (2013). Contemporary issues in teaching and learning. London, UK: Routledge.

Yang, A. V. (2005). Comparison of the effectiveness of cooperative learning and traditional teaching methods on Taiwanese college students' English oral performance and motivation towards learning IUnpublished Adoctoral dissertation). La Sierra University, Riverside, CA.

$\mathrm{Yu}, \mathrm{J}$. (2004). Problems and strategies of teaching English in large college classes. Journal of Chongqing University of Post and Telecommunication (Social Science), 3(1), 139-140.

Zhang, H., Peng, W., \& Sun, L. (2017). English cooperative learning mode in a rural junior high school in China. Journal of Education and Training Studies, 5(3), 86-96. https://doi.org/10.11114/ jets.v5i3.2199

Zughoul, M. R. (2003). Globalization and EFL/ESL pedagogy in the Arab world. Journal of Language and Learning, 1(2), 106-140. 